\title{
Bringing the Economy Back In: Hannah Arendt, Karl Marx, and the Politics of Capitalism
}

\author{
Onur Ulas Ince, Koç University
}

This article engages with the question of how to construct modern economic relations as an object of political theorizing by placing Hannah Arendt's and Karl Marx's writings in critical conversation. I contend that the political aspect of capitalism comes into sharpest relief less in relations of economic exploitation than in moments of expropriation that produce and reproduce the conditions of capitalist accumulation. To develop a theoretical handle on expropriation and thereby on the politics of capitalism, I syncretically draw on Marxian and Arendtian concepts by first examining expropriation through the Marxian analytic of "primitive accumulation of capital" and second delineating the political agency behind primitive accumulation through the Arendtian notion of "power." I substantiate these connections around colonial histories of primitive accumulation wherein expropriation emerges as a terrain of political contestation. From this perspective I conclude that such putatively "economic" questions as dispossession, exploitation, and accumulation appear as irreducibly political questions.

$\mathrm{T}$ his article engages with the question of how to construct modern economic relations as an object of political theorizing by placing Hannah Arendt's and Karl Marx's writings in conversation. I argue that Arendt's account of the "rise of the social," when critically reconstructed through the lens of Marx's theory of the "primitive accumulation of capital," contributes to a political understanding of capitalism by capturing the dimensions of power, action, and violence constitutive of this economic system. The political aspect of capitalism comes into sharpest relief, I maintain, less in relations of economic exploitation than in moments of expropriation that produce and reproduce the conditions of capitalist exploitation and accumulation. A useful theoretical handle on the element of expropriation, and thereby on the politics of capitalism, can be crafted through a syncretic adoption of Marxian and Arendtian concepts. I contend that Marx's notion of "primitive accumulation" enables an analytic account of the coercive social transformations formative of capitalist relations, where Arendt's heuristic use of the term "expropriation" falls short of this task. At the same time, Arendtian notions of "power" and "action" offer the theoretical vocabulary necessary for delineating the political agency behind primitive accumulation, which Marx's account fails to develop by reducing primitive accumulation to an essentially economic process in the transition to capitalism. I conclude that a productive perspective on the politics of capitalism can be crafted by recasting Arendt's notion of expropriation as primitive accumulation and reappraising primitive accumulation through the lens of power and action.

This inquiry takes its originary cue from Arendt's reflections on the "social," which constitutes the pivot of her critique of capitalism and its detrimental impact on the conditions of participatory politics, including the erosion of stable political institutions, shrinkage of the public realm, and the emergence of undifferentiated mass societies governed by bureaucratic technocracies. While these insights have been welcomed by recent commentators as an opportunity for revitalizing democratic theory, Arendt's conceptual distinction between the "social" and the "political" has found mixed reception. For the skeptics, this represents a transhistorical and untenable distinction whereby the social signifies a specific domain centered on issues of material reproduction that must be kept separate from a rarefied sphere of politics reserved for speech, deliberation, and judgment (Benhabib 1996; Bernstein 1986; Pitkin 1998). ${ }^{1}$ For the sympathetic interpreters, the social is a historical category that encompasses the governmental dis-

Onur Ulas Ince (onurince@ku.edu.tr) is assistant professor of political theory, Koç University, Rumelifeneri Yolu, Sariyer 34450, Istanbul, Turkey.

1. Seyla Benhabib perceives the social to be an index to Arendt's "phenomenological essentialism," while Hanna Pitkin interprets it as a mystified expression of modern alienation as reification. Richard Bernstein dismisses the term altogether as too inconsistent to perform any serious analytical work.

The Journal of Politics, volume 78, number 2. Published online January 15, 2016. http://dx.doi.org/10.1086/684596 
courses and biopolitical strategies regnant under capitalism, which discloses the limits of subjecting socioeconomic considerations to political judgment and action (Duarte 2007; McClure 2007; Owens 2012a).

While Arendt's ambivalent deployment of the term "social" warrants these contradictory readings, ${ }^{2}$ I maintain that her discussion of the rise of the social, when understood in historical terms, remains a valuable departure point for a political understanding of capitalism for two reasons. First, Arendt's critique of the social squarely opposes the liberal and Marxist employments of capitalism, as either the end of history or a stage toward human emancipation, neither of which opens to contestation a conception of historical progress predicated on material productivity and economic expansion (Rist 2009, 101-2). ${ }^{3}$ Arendt's corollary objection targets the tendency to collapse politics into a conflict of "social interests" over the management of economic growth, whether this takes the form of trickle-down economics, welfarist redistribution, or collectivization of economic assets. Second, Arendt's conceptual elucidation on power and violence furnishes crucial analytic categories for delineating the political agency behind the actions and processes that have been historically constitutive of capitalist relations of production, even though, as I argue below, Arendt herself stops taking this theoretical step. The radical contingency of Arendt's notion of "power" as the collective human agency capable of inaugurating something new and unpredictable offers an alternative way of thinking about the history of capitalism as a long record of open-ended political struggles that cannot be dissolved into prescripted historical narratives of human improvement or class conflict.

Yet for this line of theorization to live up to its potential, I contend that Arendt's account of the rise of the social and its conceptual cognate, the "social question," needs to be placed in critical dialogue with Marxian political economy around the key concept of "expropriation" that Arendt (1958, 248) cites in the last chapter of The Human Condition among the "great events [that] stand at the threshold of the modern age." With a few notable exceptions, this element has received scant attention in recent literature on Arendt and not without reason, since Arendt herself relegates expropriation to a sideshow in her analysis of modern world alienation, in which the center stage is claimed by modern natural

2. On Arendt's ambivalent deployment of cardinal distinctions in The Human Condition (1958), whereby she moves between "territorial" (divisive) and "relational" (connective) formulations, see Markell (2011).

3. A major inspiration for Arendt's critique of the modern ideology of progress is Walter Benjamin's philosophy of history. See especially "On the Concept of History" (Benjamin 2006). sciences. ${ }^{4}$ As Kirstie McClure $(2007,91)$ aptly notes, while the "process of accumulation" and the corollary problem of expropriation are "central element[s] in her account of the emergence of 'society," their development and ramifications is "a story that Arendt does not really tell." Similarly, Steven Klein $(2014,857)$ submits that Arendt's ambivalence toward the modern welfare state principally stems from her "undifferentiated and exaggerated understanding of expropriation." What gets lost in this conceptual inattention is the possibility of thinking of expropriation as a terrain of political struggle that has been historically resolved in favor of the emergence and institutionalization of the social, understood as a political-economic constellation composed of capitalist relations of production and administrative state apparatuses for promoting, directing, and managing them.

In order to recover and reconstruct this possibility, I turn to Karl Marx's notion of "ursprüngliche Akkumulation," rendered as the "primitive accumulation" or the "original accumulation" of capital, wherein one finds the most theoretically sophisticated explorations of the process of expropriation in the genealogy of capitalist modernity. Refracting expropriation through the prism of primitive accumulation, I contend, shines light on the elements of power, action, and violence operative in historical processes of social transformation constitutive of capitalism, and calls for rethinking putatively "economic" questions, such as dispossession, exploitation, and accumulation, in irreducibly political terms. Constructing a political account of capitalism, while syncretically drawing on Marx and Arendt's insights, requires arguing against both thinkers, who similarly tend to treat expropriation as a process without political agency: Arendt, by casting expropriation as an impersonal force of quasielemental character that gives birth to the "society of laborers"; Marx, by specifying actors of expropriation but subsuming their actions under the historical laws of motion of economic development, wherein violent expropriation becomes the "midwife of history."

In sketching this problematic, the article proceeds in three sections. The first section surveys and systematizes Arendt's remarks on expropriation, scattered across several texts and two decades, triangulating the theoretical coordinates of this element in her analysis of the birth of capitalist modernity. The second section delves into Karl Marx's reflections on primitive accumulation, which Arendt adopts through Luxemburg's analysis of imperialism to substantiate her arguments about modern "worldlessness," "pro-

4. Important exceptions to this relative neglect are Klein (2014), McClure (2007), and Owens (2011, 2012a). 
cess thinking," and the bourgeoisie's conflation of power and violence. The third and final section critically compounds Marx and Luxemburg's seminal arguments with recent colonial historiographies of primitive accumulation to suggest the centrality of expropriation to the consolidation of not only capitalist relations but also ideological-institutional forms of the nation-state in its postcolonial and settler-contract variants. This last section also highlights that expropriation is not an amorphous historical force that "happens" to people but a terrain of political contestation with concrete actors pursuing contending societal visions, in which the very politicaleconomic configuration of the social is at stake. I conclude that a focus on the extra-economic and at times extra-legal character of early-modern expropriation throws into relief the political elements inscribed both at the origin and in the logic of capitalism. Training the Arendtian concepts of power and action on the genealogy of capitalism discloses the "political constitution of the social."

The other underplayed element in Arendt's story of modernity, the "exploration" of the entire globe, remains beyond the immediate purview of this article, although it figures in this analysis when it interfaces with the problem of expropriation and the rise of the social. Such interfaces are thickest when the history of capitalism is cast as a global rather than a European history, a move that represents a corrective as much to Marx as to Arendt who both adopt a Eurocentric framework of historical analysis. Overall, my purpose in putting Arendtian and Marxian terms in conversation is neither to vindicate one against the other (Jay 1985; Pitkin 1998) nor to reconcile the two as essentially congruent thinkers (Ring 1989). Rather, the ultimate purpose of this essay is to develop a political perspective on capitalism from the fragments extracted from Arendtian and Marxian frameworks to suggest the inescapability of thinking about economic questions as irreducibly political questions.

\section{EXPROPRIATION AS MODERN WORLD ALIENATION}

The problem of forcible dispossession and dislocation, conceptualized as "primitive accumulation" or "expropriation," forms a continuous if occasionally subterranean stream that runs through Arendt's works. The notion of expropriation makes its debut in The Origins of Totalitarianism (Arendt [1951] 1973) as part of the effort to understand the logic of expansion that drives the nineteenth-century phenomenon of imperialism. ${ }^{5}$ The operative term that Arendt uses here

5. Many of the key ideas in the Origins are prefigured in two essays that Arendt published in 1946, where she engages with Marxian theories of imperialism (1946a, 1946b). The concept of expropriation, however, is is the "primitive accumulation of capital," coined by Marx ([1867] 1976) in the last section of Capital, vol. 1. The formative role of primitive accumulation in the history of capitalism is acknowledged in a passing remark as the process "which gave birth to the bourgeoisie" and "changed the very conception of property and wealth" (Arendt [1951] 1973, 145), prefiguring some of Arendt's reflections of expropriation and worldlessness in The Human Condition. However, at the center of her analysis is Luxemburg's expanded treatment of primitive accumulation as the means by which the capitalist mode of production devours noncapitalist strata and countries in order to reproduce itself, a process that finds its most naked and violent forms in "colonial policy" ([1913] 2003, 328-47). "The original sin of simple robbery," Arendt writes, "which centuries ago made possible the 'original accumulation of capital' (Marx) and had started all further accumulation, had eventually to be repeated lest the motor of accumulation suddenly die down" ([1951] 1973, 148).

The "original sin of simple robbery" invoked here refers to Marx's account of the forcible separation of the direct producers from the means of production in late-medieval and early-modern Europe, which gave rise to the institutional conditions of the "capital-relation": capitalist private property, a mass of dispossessed wage laborers, and a commodity market in the means of subsistence ([1867] 1976, 875-76). Unlike Marx, Arendt does not pause to explore the significance of this originary dispossession for theorizing capitalism as a historical formation. While Arendt's specific focus on totalitarianism rather than capitalism might explain this inattention, as I elaborate below, this is an oversight that blocks from view certain political aspects of the rise of the social. ${ }^{6}$ The cyclical recurrence of primitive accumulation as imperialist expansion represents for Arendt the onslaught of capitalism as a worldless economic system on the fragile political institutions of the world. It was this structural imperative, she later adds, that impelled the political emancipation of the bourgeoisie and convinced this class to "shake off the restraints of the Western tradition" (Arendt [1951] 1973, 156). Locating the concrete mechanism of this breakdown in the "alliance between capital and

missing in these writings. In a letter to Karl Jaspers in 1951, Arendt speaks favorably of Marx's essay, "Debates on the Law on Thefts of Wood," which, by Marx's own account, was an inspiration for his turn to political economy (Arendt 1992, 167).

6. For a similar point, see Klein 2014. Klein's direct focus on Arendt's understanding of expropriation is a welcome intervention. Nonetheless, his own interpretation of expropriation entirely passes over its theoretical antecedents in Karl Marx and Rosa Luxemburg and thereby misses some of its crucial implications for thinking about capitalism and the social. 
the mob," Arendt builds on Luxemburg's thesis of overaccumulation of capital for explicating the political consequences of colonial policy. ${ }^{7}$ These include the proliferation of unaccountable forms of power and means of violence in imperial bureaucracies that then return to haunt European metropoles, and the ominous symbiosis between the "unlimited accumulation of capital" and the "unlimited accumulation of power" that inundates the political principles and institutions of the nation-state (143). ${ }^{8}$ As Karuna Mantena $(2002,88,92)$ astutely observes, this represents a classical republican critique of empire in which "imperial despotism is seen to threaten and undo liberty at home," revised and updated by situating the drivers of despotism in modern phenomenon of expansion driven by the accumulation of capital.

The point to emphasize here is that insofar as Arendt grounds her analysis of imperialism on Luxemburg's theory of the accumulation of capital, ${ }^{9}$ she is effectively drawing on a theory of primitive accumulation, the exact historical and theoretical coordinates of which she nonetheless leaves unidentified. This inattention becomes all the more important in the light of Margaret Canovan's $(1992,19)$ observation that The Origins of Totalitarianism is "concerned with imperialism rather than with Nazism as such," and that its driving concerns animate a host of connections and tensions in Arendt's later writings. ${ }^{10}$ One such connection becomes manifest in "Karl Marx and the Tradition of Western Political Thought" (2002), the precursor to The Human Condition, in which Arendt for the first time traces the birth of "modernity" to the historical elements of the emancipation of labor, the glorification of violence as the "midwife of history," and the demand for universal freedom. At this key juncture, primitive accumulation appears as the hinge between the emancipation of labor and violence: "The development of capitalism is essentially the consequence of the violence of primitive accumulation" (Arendt 2002, 290). Although Arendt once again eschews an explication of the

7. This insight is borrowed almost ad verbatim from Luxemburg, who writes, "On this self-contradictory basis it is no contradiction at all that there should be an excess of capital simultaneously with an excess of population" ([1913] 2003, 324)

8. For a series of essays that take their cue from Arendt's examination of the "boomerang effect" of imperialism, see King and Stone (2007).

9. Arendt finds in Luxemburg's analysis a "brilliant insight into the political structure of imperialism" ([1951] 1973, 148). The theoretical influence of Luxemburg is further borne by Arendt's praise of The Accumulation of Capital in "Rosa Luxemburg," published in Men in Dark Times (1970). Also see Young-Bruehl (1982).

10. In a letter to Karl Jaspers in 1947, Arendt wrote of Origins as her “imperialism book" (1992, 68). violence-capital nexus, her introduction of the "society of laborers" as the specific mode of collective living under capitalism (311) suggests an affinity with Marx and Luxemburg's understanding of primitive accumulation as the violent process of dispossession that engenders relations of social reproduction centered on the activity of laboring. For as Arendt herself makes clear, the glorification of labor is not a theoretical invention of Marx; rather it is, in Benhabib's words, a "mentalité" corresponding to social conditions where the majority of the people, having been deprived of direct access to means of livelihood, have to sell their labor-power for subsistence $(1996,139)$.

The same themes appear in The Human Condition around the more thoroughly articulated problematic of "modern world alienation." This problematic constitutes the book's vanishing point, on which Arendt's ruminations on "labor," "work," and "action" converge. The first thing to note is the unequal emphasis allotted to the "three great events" that collude in the "flight from the world" and the reversal of the traditional hierarchy within vita activa, whereby "labor" is exalted into the defining activity of human life at the expense of speech and action. As noted by McClure, "in this account, the growth of modern sciences takes pride of place," while the exploration of the world and the process of expropriation "recede from view" $(2007,19)$. Likewise, Arendt's scintillating exposition of the eidos of animal laborans lacks a matching account of the concrete historical developments that have led to its triumph, prompting John McGowan (1997a, 55) to conclude, "Arendt, in fact, is neither very good at nor very interested in offering underlying causes for the shift in the sensibility she describes." Corroborating these observations, Arendt first attributes the origins of world alienation to expropriation and accumulation of wealth $(1958,257)$, only to explicitly dismiss the latter's importance a few pages later: "Compared with the earth alienation underlying the whole development of natural science in the modern age, the withdrawal from terrestrial proximity contained in the discovery of the globe as a whole and the world alienation produced in the twofold process of expropriation and wealth accumulation are of minor significance (264).”

The element of expropriation and accumulation, however, plays a more critical role in the book as a whole than this passage suggests. An adequate reconstruction of this role requires a focused survey of the earlier sections on property, labor, and the rise of the social.

In The Human Condition, Arendt drops the term "original accumulation" altogether, whose conceptual intension is now borne by "expropriation." Second, in many places she substitutes "process of accumulation" for capitalism. This 
vernacularization of essentially Marxian categories renders them more congruent with Arendt's peculiar critique of capitalism, which heuristically relies on the spatial separation of the public and the private derived from her discussion of democratic politics in the Greek polis (Villa 2000). ${ }^{11}$ Couched in terms of this spatial heuristics, the immediate impact of expropriation appears as the destruction of the common "world," the only space in which human plurality and uniqueness can be discovered and disclosed by speech and action in the public realm. The possibility of the public realm in turn rests on the availability of its constitutive opposite, a private space that gives human beings a stable "location" in the world and "contains," in the double sense of the term, the economic activities of labor and consumption associated with human life process. When Arendt speaks of "private property" in The Human Condition, she refers to this private space that simultaneously shelters human beings from ruthless exposure to the public gaze and shields the public space from the creeping infiltration of life processes of labor and consumption (1958, 59-63). "Expropriation" denotes the violent obliteration of the boundaries between the public and the private that at once separate and connect the two domains, the radical destabilization of the sociospatial markers it embodies, ${ }^{12}$ and (to use Polanyi's [(1944) 2001] terms), the transmutation of one's "habitation" in the world into fluid, exchangeable wealth, whereby "modern property los[es] its worldly character"13 (Arendt 1958, 71). With the loss of the steady opposition between the public and the private, "the social" is born.

Expropriation also conceptually marks the "penetration of the household (that is, economic and administrative) concerns into public life" (Villa 2000, 10) where they are subjected to governmental strategies that manage collective laboring activity and the material wellbeing of the population. This constitutes the threshold of the social, that "curiously hybrid realm where private interests assume pub-

11. This is not to suggest that Arendt adopts the Greek polis as a template for modern politics. For an authoritative treatment of the place of Ancient Greek politics in Arendt's thinking, see Tsao (2002).

12. "Boundary" as a concept and as a spatial trope plays a crucial role in Arendt's thinking, principally by separating the human world from nature and separating yet connecting the private and the public. Arendt conceives of the political order (nomos) and institutions that make possible a distinctly human existence in terms of borders, "boundaries," "walls," and "hedges" (1958, 59-61, 190-91).

13. For an instructive treatment of the twofold nature of property in Arendt's thought, as at once the realm of necessity and a "location with an outer face," see Klein $(2014,863)$, Markell (2011, 26-27). This reading also registers an objection to Arendt's understanding of property in classical terms, as the condition of independence and leisure necessary for nondomination. See Markell (2008). lic significance" and "the fact of mutual dependence for the sake of life and nothing else assumes public significance" (Arendt 1958, 35, 46). ${ }^{14}$ The conceptual twin of expropriation is "appropriation," which signifies the drive to seize the world, not in the form of "private property" as sketched above but as "wealth" for the purpose of further accumulation of wealth. In order for wealth to turn into "capital," however, it requires the "emancipation of labor," which is made possible by expropriation that releases "labor power as the specifically human mode of the life force which is as capable of creating a surplus as nature herself" (108). ${ }^{15}$ The "emancipation of labor is," if not ironic, than certainly a paradoxical term, for it achieves legal freedoms for the laborer and tremendously accelerates the accumulation of capital only by subjecting the mass of people to the imperatives of laboring for livelihood, thereby perpetually binding the society of laborers to the realm of biological necessity, to a condition of real unfreedom. Expropriation, appropriation, and the emancipation of labor coalesce into a processual dynamic of accumulation that unleashes the "unnatural growth of the natural" (47) and degrades the world into essentially a mass of consumer items produced and devoured by the interminable and ever-expanding metabolism of society (125-26). ${ }^{16}$

It is only in the light of these considerations that we can appreciate the full import of Arendt's historical equation of the onset of the "modern age" with the "expropriation of the poor" in a passage that is worth quoting at length:

The enormous and still proceeding accumulation of wealth in modern society, which was started by expropriation - the expropriation of the peasant classes which in turn was the almost accidental consequence of the expropriation of the Church and monastic property after the Reformation - has never shown much consideration for private property but has sacrificed it whenever it came into conflict with the accumula-

14. For a comprehensive treatment of the "social" as the pivot of Arendt's historical analysis of capitalism and modern state administration, see Owens (2012b).

15. On the significance of labor's capacity to create "surplus," see Terada (2011).

16. The cryptic term "unnatural growth of the natural" becomes intelligible if understood in terms of the purposiveness of fundamental human activities. "Human condition restrains ownership to the actual needs of life," the satisfaction of which temporarily liberates human beings from biological necessity and enables them to enter the public realm for political deliberation (Arendt 1946a, 615). In a society of laborers, the natural realm of necessity is unmoored from these purposive limits and absorbs the entire body politic. 
tion of wealth. Proudhon's dictum that property is theft has a solid basis of truth in the origins of modern capitalism. ... Individual appropriation of wealth will in the long run respect private property no more than the socialization of the accumulation process. (Arendt 1958, 66-67)

As a boundary-destroying force, expropriation therefore replaces the "permanence of the structure" of private property with the "permanence of the process" of capital accumulation, the subject of which is not individual property owners but the "society" as a whole. With the "liberation of the life process" (Arendt 1958, 47), the society of laborers resembles less a distinctly human community of unique individuals than "a society very similar to that of the ants and bees" ([1951] 1973, 145). ${ }^{17}$ The governmental form corresponding to this hive-minded, conformist, collective existence is the distinctly unpolitical edifice of bureaucracy in which "state and government gives place to pure administration" $(1958,45)$.

With the exception of a passing remark on the role of "expropriation by force" in the "early stages of capitalism," On Revolution (1962) is barren of any explicit mention of expropriation, even though, as I argue at the end of this article, its theoretical implications insinuate themselves deeply into the problematic of the "social question" to which Arendt devotes one-third of the book. The subject resurfaces in an interview published as "Thoughts on Politics and Revolution" in Crises of the Republic (1972). Asked to comment on the Cold War alternatives of capitalism and socialism, Arendt dismisses the difference between the rival systems as spurious on the grounds that they share a fundamental expropriatory logic. While capitalism "owed its start to a monstrous process of expropriation such as has never occurred in history before," "what has actually happened in Russia" was simply the "process of expropriation [that] has been carried further" (1972, 211-12). ${ }^{18}$ Based on this commonality, Arendt conjectures that perhaps "expropriation is indeed in the very nature of modern production," a process

17. The choice of metaphor is not accidental. In eighteenth-century political and economic thought, the nonhuman sociability of "ants" and "bees" was often invoked to convey the spontaneous harmony of the market-cum-civil society, which emphatically excluded political deliberation, judgment, or decision.

18. There is more than mere imagistic analogy here, since the policy identified by Arendt was self-consciously and self-righteously labeled "socialist primitive accumulation" by Yevgeni Preobrazhensky in the mid1920s and implemented by Joseph Stalin in the 1930s with a cruelty that could be sanctioned only by the "faith in history and its bloody and grandiose demands" (Arendt 1994, 278). whose momentum can be arrested only by "legal and political institutions that are independent of the economic forces and their automatism" (212). Capitalism and socialism's shared comprehension of property as an instrument of production in a system of socialized labor, rather than a private place from which to enter the public realm, vitiates any meaningful difference between the two systems, thus rendering irrelevant, for Arendt's purposes, the Marxian question of class as predicated on the ownership of the means of production. Instead, the solution that Arendt envisions centers on a property-owning society to be achieved through institutional arrangements that allow dispossessed masses to "regain property" and reinstate the boundaries between political and economic processes. ${ }^{19}$

What calls for further elaboration is the theoretical significance of this Marxian notion that Arendt adopts through Luxemburg, yet without explaining its analytic function. On the one hand, expropriation appears as an essentially historical element in "society's victory in the modern age," whose story of "at least three centuries" Arendt narrates $(1958,45)$. On the other hand, the process of world alienation triggered by expropriation, while historically contingent, is not a random chain of events; it has a definitive logic and tendency to "assume even more radical proportions if it is permitted to follow its inherent law" (1958, 257; emphases added). As I elaborate in the next two sections, the ambiguity of these passages can be clarified by identifying the elements of "power" and "action" behind historical processes of expropriation that set in motion the accumulation of capital and associated governmental forms that, once institutionalized, assume the semblance of an autonomous, impersonal, unstoppable "force," akin to natural laws or laws of history. It is the ideological sway of this semblance that underpins liberal and Marxian faith in progress as the liberation of productive forces of society, from which, for all her skepticism, Arendt's own reflections on the rise of the social are not exempt. In order to apprehend the political constitution of the social that eludes Marx and Arendt alike, we need to delve deeper into primitive accumulation and the element of power driving it.

\section{EXPROPRIATION AS PRIMITIVE ACCUMULATION}

As mentioned above, Arendt dates the great event of expropriation back to the aftermath of the Reformation and the "earlier stages of capitalism." Likewise, in her discussion

19. Arendt's call to cordon off politics from economic processes, paralleled by her prescription of the "social issues" to the expertise of specialized administrators, has raised a red flag for recent interpreters. For particularly sharp frontal criticisms, see Pitkin (1981) and Leonard (1997). 
of the French Revolution, we find the acknowledgment that "social and economic matters had intruded into the public realm before the revolutions of the late eighteenth century," and "the transformation of government into administration" had already become a "characteristic of absolutism" $(1962,91) .{ }^{20}$ What is left unexplained, as Pitkin notes, is "how capital accumulation, a rule-governed elite, and despotic monarchy are related and form aspects of the social at this stage" $(1998,15)$. To address this question, we revisit Marx's investigation of the early-modern configuration of primitive accumulation and state power in Europe, as this account, expanded by Luxemburg's analysis of imperialism, furnishes the theoretical armature of Arendt's thinking on expropriation and capitalism.

The last part of Capital, vol. 1, titled "The So-Called Primitive Accumulation," is an inquiry into the historical origins of the capitalist mode of production, congruent with the volume's overall purpose of historicizing the allegedly universal categories of classical political economy. ${ }^{21}$ Marx begins by pillorying Adam Smith's projection of the frugality of the modern capitalist back into time immemorial as the basis of the "original accumulation" of capital. Against such "insipid childishness," Marx offers an account of the historical role of "violence" in the destruction of noncapitalist forms of social reproduction and their reconstitution along capitalist lines. Written in letters of "blood and fire," the story of primitive accumulation begins with the expropriation of the agricultural producers, epitomized by the English Enclosures and Highland Clearances. It continues with the brutal repression of the dispossessed under maximum wage laws and the "bloody legislation" that criminalize vagrancy and vagabondage under the penalty of mutilation, forced labor, and transportation. At home, it includes protectionism, overtaxation, and national debt as instruments of public dispossession and private concentration of

20. Here I broadly follow McClure and Owens's strictly historical understanding of and analytic distinction between the "rise of the social" and the "social question." The "social" denotes the broader interface between the historical development of capitalist social forms and the concomitant invention of administrative state apparatuses for managing them. The "social question" emerges as the context-specific problems or crises that erupt in this interaction, be it the seventeenth-century problem of vagabondage incited by the English Enclosures or the nineteenthcentury question of how to integrate the industrial laboring class to extant political institutions (McClure 2007, 89, 101; Owens 2011 17-20). A much more precise intellectual history of the merger of statecraft and economic management is to be found in Hont (2005).

21. For Marx as for Arendt, political economy represents a historically specific field of knowledge, analysis, and policy devised to comprehend the novel social reality of an independent economic domain originating in eighteenth-century Europe. capital..$^{22}$ In the colonies, it assumes global proportions with the Atlantic slave economy and the plunder of South and Southeast Asia (Marx [1867] 1976, 873-913). In their capacity of annihilating traditional social structures and clearing the path for capitalist relations, these moments of primitive accumulation constitute the "prehistory" of capitalism. Foregrounding the essentially coercive character of these processes, Marx notes "in actual history, it is a notorious fact that conquest, enslavement, robbery, and murder, in short, force play the greatest part," a note that reaches a crescendo when he adds, "These methods . . . all employ the power of the state, the concentrated and organized force of society, to hasten, as in a hothouse, the process of transformation of the feudal mode of production into the capitalist mode, to shorten the transition. Force is the midwife of every society which is pregnant with a new one" (915-16).

In order to appraise the significance of this last sentence for the politics of capitalism, we need to take a detour through Arendt's conceptual distinctions between "power," "violence," and "force," broached in "On Violence." For Arendt, "force" is characteristically impersonal and objective, be it the "forces of nature" or the "force of circumstance" (1972, 144). It impresses itself on human beings in the form of an elemental "necessity" beyond human control such as the imperatives of biological survival. "Violence," on the other hand, is distinguished by its strict instrumentality as the mediating term in the relations that human beings enter with the world and with one another (145). It acquires its meaning only in its exercise to establish the human subject's sovereignty over the world of objects and other human beings, most importantly, for mastering the force of necessity by appropriating nature or commanding the labor of others (Arendt 1958, 114). "Power" stands in stark contrast to both force and violence. Unlike "force," which is experienced as external to human agency, power is subjective and encapsulates that unique "human ability not just to act but to act in concert" (1972, 143). Unlike violence, which is manifested in the subjectobject relationship, it is irreducibly intersubjective and noninstrumental. It can emerge only when a plurality of human beings acts together for a shared purpose, yet this very plurality renders the results of such action unpredictable and capable of bringing into world something truly new that defies the sovereign pretensions to domination and control inherent in instrumental relations.

22. In "Thoughts on Politics and Revolution," Arendt also categorizes similar policies as an ongoing and "mild form of expropriation" (1972, 212). 
Viewed through this conceptual framework, Marx's designation of violence as the midwife of history imagines history as a "process," the agents of which are no longer "men" in their plurality of intentions and concerted action but "mankind" as an undifferentiated, unified subject. Arendt partially exculpates Marx by adding that his exaltation of the realm of necessity as "glorification of mute violence" and "glorification of labor" is mainly an index to the factual transformation of social relations that heralds the dawn of modernity $(2002,291,294)$. Marx inherits and casts in dialectical mold the bourgeois faith in the inevitability of progress, evinced in eighteenth- and nineteenthcentury theories of sociohistorical evolution, from the "primitive" to the "civilized" society through the transformative violence of primitive accumulation. For Arendt, the real problem with Marx is, in Waseem Yaqoob's (2014, 404) words, his "indiscriminate reconciliation" to this violence that is rooted in a Hegelian faith in history, whereby primitive accumulation is accorded the world-historical role of universalizing and consummating the contradictions of capitalism as the necessary condition of its dissolution. Under the acerbic tone of Marx's account of primitive accumulation, Arendt discerns a dangerous acquiescence to violence as the mediating element that miraculously transmutes the compulsion to labor under the force of necessity (alienated labor) into its opposite, universal freedom and equality. ${ }^{23}$

Yet in spite of her incisive criticism of Marx's confusion of power and violence and his reduction of both to an instrument of the forces of historical laws, Arendt falls into a similar position when she hypostatizes "the social" as an impersonal force that has "transformed all modern communities into societies of laborers and jobholders" (1958, 46). Behind this hypostatization is Arendt's subtle parsing out of the political and the social on the basis of the distinction between power and force. "All political institutions," Arendt writes, "are manifestations and materializations of power," and they rest on the "continuation of the consent that brought the laws into existence in the first place" (1972, 140, emphasis added). In contrast to her predication of the political on action that instantiates power, she consigns the social to the realm of force as the "energy released by physical or social movements" (144, emphasis added). Underpinning Arendt's equation of the social and

23. This remains a trenchant critique, a sort that Marx himself had to confront toward the end of his life. His ethnographic notebooks and Russian letters betray a profound reconsideration of the linear historicism implicit in his earlier accounts, as well as reflections on alternative paths to socialism that are not necessarily mediated by the violence of primitive accumulation. See Anderson (2010) and Shanin (1983). the natural is her understanding of the former as partaking in the same blind automatism as the laws of nature. This leads her to a fixation, in Klein's words, on the "process character of expropriation at the expense of the web of human relationships that sustains it" $(2014,10)$.

Arendt writes that "nothing . . . is more common than the combination of violence and power" (1972, 145-46), and to point out the political element of power behind the violence of expropriation, we ought to examine the formal theory of primitive accumulation that is interlaced with Marx's story of capital's origins. ${ }^{24}$ True to his relational conceptualization of capital, Marx defines primitive accumulation not as the accumulation of material wealth but as the process that creates the "capital-relation" between, on the one hand, privately owned means of production and subsistence, and on the other, dispossessed and legally free labor. At the outset of his discussion of primitive accumulation, Marx identifies the concept as "the process which divorces the worker from the ownership of the conditions of his own labor ... whereby the social means of subsistence and production are turned into capital, and the immediate producers are turned into wage-labourers" ([1867] 1976, 874). ${ }^{25}$ The significance of this definition is threefold. First, in contrast to Arendt's rendering of this narrative, where she casts "the social" as an impersonal historical force that effects capitalist transformation, Marx's conceptualization allows for identifying historically specific contexts, actors, and processes through which labor is "emancipated" and human beings are reduced to bearers of labor-power. ${ }^{26} \mathrm{~A}$ political rendering of this account a la Arendt, however, requires reading Marx against Marx by unmooring these actors and processes from his historicist employment in which they fade into scripted performances in the grand world-historical drama of the "rise of capitalism." A similar ambivalence attends Marx's

24. Primitive accumulation as a concept is not without controversy, which has found renewed vigor after David Harvey's (2003) resuscitation of the term in the form of "accumulation by dispossession." For excellent overviews of the twentieth-century debates, see de Angelis (2004); Sanyal (2007). For a recent survey of the extant literature and a theoretical reappraisal, see Ince (2014).

25. In the same section, Marx introduces a tremendously helpful distinction between capitalist private property and individual private property, which captures and clarifies the essence of the distinction Arendt draws between property and wealth ([1867] 1976, 889).

26. Arendt does identify a number of historical actors in the Origins of Totalitarianism, such as the bourgeoisie, the mob, and the imperial bureaucracy. However, these actors are post-factum creatures of capitalist relations who further the expansionary and essentially nonpolitical dynamic of capital accumulation. In the place of the origins of capitalist relations and the particular human agency therein, we encounter a gaping hole, which is later filled by the amorphous notion of the "social" in the Human Condition. 
view of the violence operative in expropriation. Marx gestures at a political conception of expropriation when he states that primitive accumulation depends on the "concentrated and organized force of society," signaling and opening up a space in which Arendt's notions of power and action can gain theoretical traction. Unfortunately, he quickly forecloses this potential by adding that this force "is itself an economic power" that "hasten[s], as in a hothouse, the process of transformation from the feudal mode of production to the capitalist mode" (915-16). Nonetheless, as I discuss in the next section, when disentangled from its historicism and economism, Marx's theory of primitive accumulation has much to offer for politicizing the social by highlighting the dimension of power behind the violence of expropriation constitutive of capitalism.

Second, Marx's theoretical construction of primitive accumulation inscribes it in the very core of the capital-relation, which "not only maintains this separation [between the workers and the conditions of labor], but reproduces it on an ever expanding scale" (874). To the extent that workers acquiesce in the requirements of the capitalist mode of production as self-evident economic laws, extra-economic coercion yields to the "silent compulsion" of the economy and the workings of the invisible hand of the market. In other words, Marx's theory of primitive accumulation offers a handle on the institutionalization of expropriation in the society of laborers, ${ }^{27}$ whereby, to use Arendtian terms, the "force" of biological necessity rules after the "violence" of direct expropriation recedes. Third and by extension, by anchoring the "victory of animal laborans" in concrete mechanisms that give rise to the "society of laborers," Marx's theory casts into relief the structural conditions that enable, if not dictate, the "purely social perspective" through which all human activity is understood in terms of "making a living" (Arendt 1958, $88,127)$.

The crucial implication of these observations is that, when viewed through the lens of primitive accumulation, "the social" ceases to be an experiential category, the expression of the laboring mentalite bursting the confines of the private and infiltrating the public realm. It reappears as a historically specific network of concrete social relationships that hinge on the compulsory mediation of access to means of livelihood by the imperative to generate a surplus for capital accumulation. Whether this compulsion materializes in brute violence or strategic instrumentalization of necessity, it har-

27. Arendt obliquely gestures at the institutionalization of expropriation in her discussion of "bourgeois philosophy" in relation to Hobbes. The key element here is the designation of private property and its accumulation as a public concern (Arendt 1946a, 609-14; 1946b, 6-7). bors a political dimension of constituent power, as I elaborate in the next section. ${ }^{28}$

One critical attempt to overcome the historicism that structures Marx's story of transition to capitalism is supplied by Luxemburg's The Accumulation of Capital ([1913] 2003), which renders it more congruent with Arendt's reflections on expropriation. While Marx provides the theoretical framework for capturing violent expropriations constitutive of the capital-relation and its institutionalization under the economic coercion of wage labor, Luxemburg's study forcefully argues that the originary violence of primitive accumulation can never be dispensed with even after the capitalist mode of production stands on its own two feet. Despite Arendt's doubt that Luxemburg "was a Marxist at all” (1970, 38), Luxemburg clearly adhered to Marx's categories in her historical analysis of capitalism as a contradictory social formation..$^{29}$ Specifically, her examination of modern imperialism builds on Marx's theory of primitive accumulation and works through some of the major impasses afflicting the latter. At the core of Luxemburg's analysis is the thesis that capitalism as an economic system cannot autonomously reproduce itself but has to rely on renewed processes of primitive accumulation..$^{30}$ In contrast to Marx's historicist understanding of primitive accumulation as a phase that is left behind by the advent of the "expanded reproduction" of capital, Luxemburg conceives of the continuous expropriation of noncapitalist social strata and countries as endemic to capital's life process. Here we find an unambiguous line of theoretical continuity between Luxemburg's insight and Arendt's conjecture that "expropriation is indeed in the very nature of modern production" $(1972,212)$.

By extension, Luxemburg unshackles the violence of expropriation from its early-modern moorings and renders it coterminous with the history of capital as whole. "Force is the only solution open to capital; the accumulation of capital, seen as an historical process, employs force as a permanent weapon not only at its genesis, but further on down

28. By "strategic instrumentalization of necessity," I mean the consciously devised methods to mobilize economic need to compel people to labor. Such thinking dates at least back to the seventeenth-century, when the laboring poor was perceived by statesmen and pamphleteers to be "idle, surly, and unwilling to work 'if two days pay will keep them a week." The proposed solution was to reduce average wages through maximum wage legislation to compel laborers to work (Appleby 1978, 145-46).

29. Arendt's effort to salvage Luxemburg from Marxism is in tune with her more general disposition for "breaking with class analyses while retaining a Marxist emphasis on imperialism" (Yaqoob 2014, 401).

30. Luxemburg's core theoretical tenet is "the realization of surplus value for the purposes of accumulation is an impossible task for a society which consists solely of workers and capitalists" ([1913] 2003, 330). 
to the present day" ([1913] 2003, 351). In Europe and the United States, the vectors of expropriation instantiate in revolutions, wars, and coercive taxation; elsewhere, they assume the form of "colonial policy," ranging from robbing rural communities of their land to instituting brutal regimes of bonded labor. The unifying logic behind the variegated methods of expropriation is the eradication of noncapitalistic forms of social reproduction, such as "natural economy," "peasant economy," and "simple commodity production," in order to release the means of production and labor power in which capital finds room for self-expansion. Expressed in starker terms, primitive accumulation in Luxemburg's account represents the violent drive of capital to transform the entire population of the world into a "society of laborers" by deepening the capital-relation in the industrial metropoles and, as imperialism, absorbing productive practices across the globe into planetary circuits of capital accumulation.

Two important conclusions follow from the preceding analysis. First, when situated in imperialism and colonial policy, primitive accumulation illuminates the conflation of power and violence that for Arendt defines the bourgeois conception of politics. The liberation of productive forces and economic growth define the bourgeoisie's social function and historical mission. The "political emancipation" of this class through imperialism, in which the economic principle of ceaseless expansion is elevated to a political objective, leads to the collapsing of politics into the project of violently demolishing noncapitalist social forms and reconstituting them in the service of capital accumulation on a global scale. The second and related conclusion is that Arendt's notion of "mankind" is less bound up with the universal viewpoint of natural sciences that looks down to the earth from the space and perceives humanity as yet another biological species that inhabits the planet. Rather, "mankind," understood as an undifferentiated whole whose common denominator is the laboring process (Arendt 1958, 256), finds the conditions of its historical reality in global processes of primitive accumulation that are coeval with the history of capital. Accordingly, expropriation as primitive accumulation pushes Arendt's account of the rise of the social beyond the unit of the nation-state and opens up a historical vista of colonial empires in which to situate not just world alienation but, more importantly, world destruction.

This last element has been a source of insight in recent investigations of the entangled genealogies of capitalism, European imperialism, and postcolonial polities, which push beyond Marx's historicism and Arendt's undifferentiated treatment of expropriation. Placing expropriation in colonial perspective reveals its stakes to be not just capitalist transformation but a broader reconfiguration of political institutions through which material and social reproduction is regulated. Second, it shows that such transformation is not a unilateral process that rolls over its victims who passively suffer it, but a political terrain punctuated by resistance to expropriation and contestation over its vectors and limits. The next section investigates these themes around recent scholarship on the postcolonial nation-state, the settlercontract, and early-modern class struggle.

\section{EXPROPRIATION AS A POLITICAL TERRAIN}

That primitive accumulation is not merely an economic phenomenon can be illustrated by an examination of the developmental nation-state that emerged as the institutional heir to European colonial empires in the aftermath of the Second World War. Recent postcolonial scholarship has persuasively argued that the developmental state effectively took over the mandate of the colonizing powers to develop the economic resources of colonial territories through direct and indirect expropriatory policies (Anghie 2005; Pahuja 2011). Yet the continuity in economic policy is only half of the story. Perhaps more fundamental is the inheritance from colonial empires of a vision of progress understood as the construction of a politico-legal order comprising a civil society of rights-bearing citizens and a representative government embodied in the nation-state. In a path-breaking study, Partha Chatterjee (1993; also see Chatterjee 2011) argues that these political indicators of "development" are embedded in a broader history of capital in which primitive accumulation plays a pivotal role. Primitive accumulation in Chatterjee's account represents "nothing but the destruction of precapitalist community, which, in various forms, had regulated the social unity of laborers with their means of production" (235). Emplotted in the narrative of capitalist modernity, the community "becomes relegated to [capital's] prehistory, a natural, prepolitical, primordial stage in social evolution that must be superseded for the journey of freedom and progress to begin. And since the story of capital is universal, community, too becomes the universal prehistory of progress, identified with medievalism in Europe and the stagnant, backward, undeveloped present in the rest of the world" (Chatterjee 1993, 235).

Chatterjee's observation distills the essence of the postwar "modernization theory" that held responsible for the poverty of the "underdeveloped" nations the stasis of their "traditional" social structures. The corollary prescription was a comprehensive reconstruction of these societies along the lines of Occidental rationality that would render their political institutions congruent with a capitalist economy (Peet and Hartwick 2009). Expressed in Arendtian terms, this 
amounted to the active institution of the "social." Seen in the light of the radical aspirations of modernization, primitive accumulation appears as a political project that breaks down the governmental structures of the noncapitalist community, and gives rise to, on the one hand, the individual citizen of subjective rights, and on the other, the nation as "the only legitimate community in modern society, a role that must then be enforced by the disciplinary mechanisms of the nation-state" (Chatterjee 1993, 234). In other words, primitive accumulation belongs as much to the history of "le citoyen" (notwithstanding the older tradition behind this figure) as of "le bourgeois" (McGowan 1997a, 90).

The cautionary conclusion of this brief discussion is the danger of collapsing the understanding of "politics proper" to the Western nation-state form, which effaces the practices of collective self-government in noncapitalist communities that extend to the management of the means of production and subsistence. This is a juncture where we have to part ways with Arendt. While Arendt cannot be held accountable for exhausting the concept of the political in the modern nation-state form, she does stand susceptible to the charge of predicating the contours of the political too intimately on the Western experience and acknowledging as properly political only those revolutions and rare moments of the labor movement that belong to the EuroAmerican history $(1962,216-19) .{ }^{31}$ For instance, she has no qualms about speaking of "nonpolitical communities" under "oriental despotism," whose public sphere is not the agora or the assembly but an "assemblage of shops" (1958, 160). ${ }^{32}$ To follow Chatterjee's cue, non-Western communities find their place alongside the feudal household that for Arendt is barren of a public space and therefore of the conditions of politics. Their forms of collective selfgovernment thereby suffer a double exclusion from the domain of the political, whether it is understood as speech and action among peers or as the nominal membership in

31. Arendt's Eurocentrism has been noted by several scholars. Yaqoob writes, "Arendt's account of imperialism, while avowedly anti-colonial, was strongly Eurocentric" $(2014,391)$, while Mantena notes that for Arendt " imperialism appears only as an episode of and for European history” (2002, 103 ). Robert Bernasconi (2007) carries this critique further, contending that Arendt was not only Eurocentric, but she also actively struggled to safeguard the "Western tradition" from being blemished by Western imperialism. For a critical exchange, see Gundogdu (2011) and Klausen (2011).

32. To take this a step further, in a tragic inversion of triumphalist narratives of modernity, the "nonpolitical community" of the Orientals arguably furnishes the image that captures the deterioration of politics in the West: the modern market as the new, unpolitical public space, which is presided over by modern bureaucracy that mirrors Oriental despotism in its unaccountability. the body politic of the modern nation. Through a peculiar inversion of the eighteenth-century European image of the "Orient" as "all state and no society," Arendt depicts the same as "all society, no politics."

When we shift our focus from imperial dependencies like India to settler colonies in America, we encounter an even more striking instance of the imbrication of expropriation and the establishment of political institutions that is pivotal to Arendt's ideas on revolutionary founding and constitutionalism. Arendt famously celebrates the "colonization of North America and the republican government of the United States," as "perhaps the greatest, certainly the boldest enterprises of European mankind" $(1962,55)$. For Arendt, one of the most commendable feats of the American Revolution was its exclusion of the "social question" of mass poverty from the purview of founding a new polity. Unlike the French Revolution, where the issue of the material well-being of the populace overflowed the confines of state "policy" and came to be embodied in "the people" (1962, 60; McClure 2007, 87), the American Revolution succeeded in bracketing economic questions. This was thanks to a unique blessing of colonial America, namely, the absence of misery and wretchedness, which emblazoned it in the European imagination as the first "society without poverty" (1962, 22).

What has been lost on Arendt and contemporary commentators alike in the American case is the fact of native dispossession that underpinned the felicitous absence of poverty in colonial America, which tightly weaves together the violence of expropriation and revolutionary politics. Arendt does concede that America had a variant of the social question in the form of African slavery (1972, 71-72), the resolution of which through the American Civil War involved violence on a scale larger than the Terror (Benhabib 1996, 160-61). In "Civil Disobedience," she approvingly refers to Alexis de Tocqueville's prescience in diagnosing the United States' future bane to be the exclusion of "Negros" and "Indians" from the "original consensus universalis of the American republic" (Arendt 1972, 90). In the rest of Arendt's essay, however, "Indians" entirely disappear from the view, and the discussion is engulfed by the Negro question. ${ }^{33}$ Nor is this the first or the only time Arendt ignores the native peoples of what would become Anglophone settler colonies. In the Origins, for instance, she writes "Canada and Australia were almost empty and had no serious population problem" ([1951] 1973, 182). Therefore, Arendt (like Marx

33. This is notwithstanding that her source of inspiration, Tocqueville himself, devotes roughly equal space in Democracy in America to the discussion of Native Americans and African slaves. 
before her $)^{34}$ squarely looks past the indigenous inhabitants of the continent, whose expropriation supplied the colonial settlers with the possibility of becoming Benjamin Franklin's cherished "freeholders" $(1962,67)$.

This question is investigated in an excellent recent study by Aziz Rana (2010), who demonstrates the historical link between, on the one hand, the "settler liberty" undergirding the republican form of government in the United States and, on the other, landed property that was made available to white settlers through an essentially imperial process of territorial conquest, complete with a legal nomenclature and a discourse of civilization and savagery inherited from the British imperial tradition. American people were exempt from the dehumanizing need that blighted the French masses on the eve of the Revolution, because they held property, however modest; and they held property because they had expropriated the indigenous peoples. From this angle, the eventual intrusion of the social question into American politics in the late-nineteenth century was due as much to the closing down of the frontier and unavailability of land as to the "onslaught of urbanization, industrialization, and . . . mass migration" (Arendt 1962, 55). ${ }^{35}$

Settlerism, like developmentalism, thus brings into view the interlinked cascades of capitalist expropriation in Europe and (post)colonial expropriation elsewhere. Once conceived globally, the implications of expropriation extend beyond the rise of the social and into questions of political agency and state-formation. Under the disturbing light shone by native dispossession, the American political experiment, which Arendt describes as the closest concrete approximation to the "social contract idea" $(2002,288)$, appears as what Carol Pateman (2007) has labeled a "settler contract" - a contract that founds a new polity on the ruins of another. If "everything depends on the power behind the violence" (Arendt 1972, 148), then the element of "power" emanating from the colonial settlers' concerted action conversely depends on the violent expropriation of the indigenous peoples. A strict Arendtian interpretation might dismiss this criticism on the grounds that native dispossession belongs strictly to the economic side of the Revolution (i.e., to the

34. See Marx ([1867] 1976, 934), where he speaks of colonial land as freely available "public property."

35. In a similar vein, the failure of mass poverty in nineteenth-century Britain to translate into an explosive social question arguably owes to massive emigration to Britain's settler colonies starting in the 1840s. Once the prospects of giving land to the dispossessed of Europe by dispossessing non-Europeans wane, the problem of "surplus population" or "superfluous men" reasserts itself as a "social question," the management of which now requires other policy measures ranging from welfare to workfare to mass incarceration. See Braun (2007), Duarte (2007), and Sanyal (2007). tragic inevitability of the mastery of necessity through violence, be it through enslavement or expropriation) and is therefore nonpolitical (Arendt 1958, 114). However, the violence at work in this case, as well as the concerted action that underwrites it, are not only squarely outside the household, which renders them public, but they also proceed through the not-unselfconscious obliteration of other human communities and their forms of self-government. ${ }^{36}$ The element of power that makes such destructive expropriation practicable is not conceptually far from the "organized solidarity of the masters" over the slaves in the ancient polis, wherein Arendt observes that "a superior organization of power" is infinitely more important than "superior means of coercion" (1972, 148-49).

Viewed through the same lens, the concerted action behind the violence operative in indigenous dispossession appears not too distant from the organized solidarity of the improving landlords, merchants, and manufacturers behind the Glorious Revolution, whose ideological and institutional innovations propelled the great expropriation of the English Enclosures forward. ${ }^{37}$ And not unlike the Glorious Revolution and the eventual legalization through "Parliamentary Enclosures" of the once-unlawful expropriation of the English peasantry, the American Revolution weds political power and action to the violence of expropriation. Arendt admits that power and violence are often found entwined yet concludes, "from this, it does not follow that authority, power, and violence are all the same" (1972, 145-46). While "power" and "violence" might be categorically distinct, expropriation, particularly when placed in the context of settler colonialism, represents a peculiar case in which the two bend into each other like a Möbius strip. Expropriation and exploration, the two events downplayed in Arendt's story of modernity, return to merge in colonial America. What spells the onset of modern world alienation for Europe and its settler colonial offshoots, portends world destruction, or in James Tully's

36. Admitting the tragic necessity of such collective expropriation would bring Arendt too close to Carl Schmitt to be tenable. For his position on colonial land appropriation, see Schmitt ([1950] 2003), 349.

37. For an authoritative investigation of the political economy of the Glorious Revolution, see Pincus (2009). Arendt makes an oblique reference to this alliance when she writes, "Society, when it first entered the public realm, assumed the disguise of an organization of property-owners" who claimed protection from the public for the unhindered expansion of their wealth $(1958,68)$. This statement seems to impute an idiotic outlook to the groups and classes who promoted and benefited from the exploitation of labor, expansion of trade, and capital accumulation. Pincus convincingly argues that the champions of the new commercial order in England explicitly directed their attention to the political question of the purpose of the commonwealth, even when they resorted to the non-Republican language of political economy in doing so (1998). 
powerful words, a "historical invasion and restructuring of the non-European world [that has] dispossessed nonEuropeans of political and legal control over their resources and economies, and modified, subordinated, or replaced their forms of organization with the institutional preconditions of western legal and political domination, economic exploitation, and military control" $(2009,14)$.

Yet the history of this destruction is checkered with multiple instances of resistance to expropriation and its tendency to reduce people to mere embodiments of labor power (or in Arendtian terms, animal laborans) subject to the imperatives of capital accumulation. The English Enclosures that gave rise to the English working class also triggered antienclosure riots throughout the sixteenth century that then laid the foundations for seventeenth-century radical politics of the Diggers and Levellers who espoused a resoundingly democratic and egalitarian political and economic vision against England's nascent commercial elite (Hill 1972). But perhaps a more illuminating episode of resistance against expropriation that matches the global scope of this process is the story of the polyglot, multiethnic Atlantic proletariat whose travails Peter Linebaugh and Marcus Rediker recount in their The Many-Headed Hydra (2000). Adopting the "original accumulation of capital" as their vantage point on this history, the authors reconstruct the discontinuous eruption of struggles waged by slaves, sailors, and commoners against being reduced to mere "hewers of wood and drawers of water" in the service of expanding webs of commodity and capital that harnessed the two sides of the Atlantic. Linebaugh's and Rediker's chronicle of slave revolts in sugar plantations, mutinies in deep-sea vessels, anti-enclosure riots, and Leveller politics is rife with conscious, vocal, and articulate attempts at defending existing forms of "commoning" and inventing new ones in the face of the new vectors of expropriation and domination advanced by the enclosing landlords, merchants, slave traders, chartered companies, plantocracies, and the ascendant fiscal-military state.

The most important dimension of these struggles was that they strove for more than simply higher wages and better working conditions, or in Arendt's terms, the pursuit of "social interests" with which she indicts the modern labor movement $(1958,215-17)$. Their claims were emphatically political in the sense of envisioning and, under favorable circumstances, establishing egalitarian and democratic communities, often with fleeting success, as on pirate ships, in maroon communities of runaway slaves, transported convicts, and free laborers. Even when they were vanquished or thwarted, the aspirations of constructing alternative forms of self-government that pulsated in such attempts were never entirely extinguished. They traveled around the Atlantic, in- spiring other struggles. This is to suggest that the revolutionary tradition, whose "lost treasure" Arendt laments at the end of On Revolution, not only extends back to the proletarian struggles of the early-modern period but, more importantly, it is directed precisely against expropriation, displacement, and the worldlessness with which it threatens human communities. ${ }^{38}$ The remarkable vitality and frequency of the resistance against expropriation, especially if one considers the scale and significance of the Haitian Revolution, flies in the face of Arendt's claim that the incapacity of animal laborans for political action is evidenced in the "striking absence of serious slave rebellions in ancient and modern times" $(1958,215){ }^{39}$

To appreciate the political valence of these struggles against expropriation, however, one has to first extend one's view beyond Western Europe and America and, second, construe expropriation as a terrain of contestation with political stakes, rather than as an "unmediated, quasi-natural process" that spontaneously "happens" to people under the onslaught of "the social." Once these adjustments are admitted, recentering on expropriation as primitive accumulation can help us unravel the ambiguity of "labor" in Arendt's theory as at once a supremely "anti-political" activity $(1958,213)$ and a "public political fact of the first order" and the "political side" of the perplexities of modernity $(2002,280,284) .{ }^{40}$ For what is at stake in primitive accumulation is nothing less than the specific articulation of the laboring activity to the overall organization of collective life, in Klein's words, the "worldly, stabilizing mediations" that place social reproduction "beyond the reach of

38. A similar conclusion can be derived from Pyotr Kropotkin's ([1902] 2006) survey of traditions of spontaneous self-organization and self-management of village communities in Eurasia in Mutual Aid. The complex structures of common property, cooperation, and "folkmotes" (assemblies of collective decision making) in Kropotkin's study bear more than just imagistic resemblance to Arendt's cherished council system that flourishes during revolutionary periods. In both cases, the centralized, administrative state behaves as the nemesis of such forms of self-organization that elude its orbit. In Kropotkin's narrative, we find the village community as a bulwark against the state's attempts to dismantle common forms of property and labor and with them the institutional backbone of selfgovernment. Translated into Arendtian terms, resistance against state-led expropriation, commercialization, and proletarianization is tantamount to resistance against the encroachment of the social.

39. It should be noted that Marx himself was as uninterested in struggles against expropriation as Arendt was oblivious to them, as the world-historical mission of primitive accumulation to universalize capitalism consigned such resistances to theoretical and historical insignificance.

40. By contrast, Eli Zaretsky $(1997,222)$ finds nothing new in Arendt's conceptualization of the modern activity of laboring but a continuation of the Western tradition of degrading work and exalting idealism tied to the idea of leisure. The valorization of public activity in ancient Greece and private activity in modern societies simply express the same asymmetry. 
the market forces and instrumental economic imperatives" $(2014,866)$. Even if we admit Arendt's conception of "labor" as an inescapable human activity, its articulation can assume multiple, contending forms, among which capitalist modernity has emerged as the historically triumphant but by no means the predestined system. Construing expropriation as a principal site of contestation over different modalities of articulating labor, wherein alternatives to the "social" or capitalist variant of this articulation are at stake, shines light on expropriation's political, as opposed to economic, dimension.

\section{CONCLUSION: TOWARD POLITICIZING THE ECONOMY}

Perhaps the boldest conjecture that can be made based on the foregoing analysis is that "the social" is not so much a domain or even an outlook as distinct from "the political." Rather, insofar as the "social" signifies the constellation of discourses and strategies for securing the conditions of capital accumulation by governing human populations through biopolitical and sovereign technologies of power, it can be understood as the outcome of political struggles, dating back to the early-modern period, over competing value systems and visions of organizing collective life. That these struggles have been largely resolved in favor of the "emancipation of labor" (i.e., the forcible reduction of the human body to the mere embodiment of labor power) does not invalidate the political features of such struggles or their ongoing presence. A productive approach to the social would therefore be neither to abandon it on the grounds of its conceptual inconsistency, nor to accept it in Arendt's own terms as an essentially economic sphere of production, circulation, and consumption entrusted to public administration. Instead, the social is itself a stake in political contestation and a theoretical problematic in which one finds politics and economics, expropriation and exploitation, power and violence, and authority and ideology entwined. A serious and critical engagement with these aspects of the social necessarily expands the range of questions that circumscribe the vocation of political theory and urges it to take up questions conventionally relegated to the field of economics or political economy.

It might be objected that my political interpretation of expropriation remains ultimately an external critique that has little in common with Arendt's conception of the political based on speech, judgment, deliberation, and nonviolent action (McGowan 1997b). Such rebuttal, however, does not resolve the theoretical difficulty posed by the peculiarity of expropriation, which cannot be theorized as an "economic" category without a political remainder. Expropriation clearly does not belong to the private economy of the household (oikonomia) and the mastery of material necessity. Neither can it be comprehended as part of the public economy of the nation ("the social"), for expropriation as primitive accumulation is the very process that gives rise to the public economy in the first place, thereby eluding theorization with reference to a preexisting "social" domain. ${ }^{41}$ Expropriation at times lacks even a legal status as, for instance, when it takes the form of unlawful enclosures, settler colonialism, imperial plunder, or in short "simple robbery," that belong to the global history of capital.

Critically, such acts of expropriation are driven not by impersonal, transhistorical forces but by specific groups and classes united by a common vision and allied for realizing it in the world, by violent means if necessary. If successful, such actions can radically alter the fabric of social reality by destroying extant institutions of property and self-government and imposing new structures, no less in the Scottish Highlands after the Clearances than in Bengal after the Permanent Settlement. That such initiatives partake of the characteristics of "action" in inaugurating something new, unpredictable, and uncontrollable does not necessarily make the reality that they institute, such as the global network of capitalist relations, more desirable. These ramifications remain out of sight, however, if one categorically rejects "class" as a relevant tool of analysis in politics and reduces expropriation to a process that simply liberates the biological life process from its confinement in the household and unleashes it onto the public sphere.

A third issue brought into focus by expropriation is the global networks of economic interdependence, which receive at best passing remarks from Arendt who, in Mantena's words, "has very little to say in terms of its [imperialism's] specific and catastrophic legacy for the ex-colonial world" $(2002,104)$. The abovementioned dependence of settler freedoms on colonial dispossession is a case in point. The implications go further. For instance, in an oft-quoted passage in On Revolution, Arendt categorically denies that the social question of poverty can be resolved by political means because, she maintains, poverty is a nonpolitical, natural condition with a technical solution $(1962,63)$. "Human life has been stricken with poverty since times immemorial, and mankind continues to labour under this curse in all countries outside the Western Hemisphere. No revolution has ever solved the 'social question'" (112). More important than the ironically Benthamite premise behind this argument, reducing

41. This is also why classical political economy as the language for analyzing the social as public economy fails to supply an endogenous theory of primitive accumulation and resorts to myths to fill this constitutive gap. 
the question of poverty to the problem of scarcity leads Arendt to commit the same mystification as mid-twentieth "diffusionist" modernization theories. ${ }^{42}$ The assumption is that the nations of the Western Hemisphere have solved the problem of poverty "not by revolution but by science and technology" (Arendt 1972, 117), which, given the political neutrality of technology, can enable any developing country do the same. What is screened out is the globality of capitalism as a historically specific social formation, which not only mediates both the development and the utilization of technology but does so through fundamentally uneven and combined processes of accumulation across the planet. If colonial genealogies of capitalism are given any credence, their immediate implication for the "social question" is that the "liberation of the life process" and the resultant "abundance" in Western Europe and its settler colonies is entwined with the history of degradation, precarization, and truncation of the life process in the colonies and their postcolonial heirs. ${ }^{43}$ These entangled histories elude the grasp of a perspective that lumps together everything related to "life process" and, by counterposing it to politics, obliterates critical distinctions within the transnational social.

In conclusion, if one takes seriously the Marxian provenance of Arendt's notion of expropriation and explicates its theoretical and historical valences, one cannot avoid the challenge posed by this phenomenon to political theory. Categorically outside the private and the public economy and punctuated by the constituent power of people forming alliances and acting in concert, the process of expropriation and resistances to it contain a political element that insinuates itself into the historical development of a global and internally variegated society of laborers. The political stakes of this historical development would be clear to a whole generation of young people in Europe and the United States, who have lost not just the prospects of job security but more broadly the chances of self-fulfillment in their lifetime to neoliberal policies of austerity designed, defended, and implemented by technocrats. The times call for politicizing the economy, both in theory and praxis, opening it to deliberation, contestation, and social struggle. The question of expropriation can give us a good starting point for doing so.

\section{ACKNOWLEDGMENTS}

I would like to thank Ayten Gündogdu, Lisa Ellis, and two anonymous reviewers from the Journal of Politics for their very helpful feedback on the earlier versions of this article.

42. On "diffusionism," see Blaut (1993). The classical treatise in modernization theory is Rostow (1960).

43. For a provocative study, see Davis (2001).

\section{REFERENCES}

Anderson, Kevin. 2010. Marx at the Margins: On Nationalism, Ethnicity, and Non-Western Societies. Chicago: University of Chicago Press.

Anghie, Antony. 2005. Imperialism, Sovereignty, and the Making of International Law. Cambridge: Cambridge University Press.

Appleby, Joyce. 1978. Economic Thought and Ideology in SeventeenthCentury England. Princeton, NJ: Princeton University Press.

Arendt, Hannah. 1946a. "Expansion and the Philosophy of Power." Sewanee Review 54 (4): 601-16.

Arendt, Hannah. 1946b. "Imperialism: Road to Suicide." Commentary 1 (4): 27-35.

Arendt, Hannah. (1951) 1973. The Origins of Totalitarianism. New York: Harcourt, Brace.

Arendt, Hannah. 1958. The Human Condition. Chicago: Chicago University Press.

Arendt, Hannah. 1962. On Revolution. New York: Viking Press.

Arendt, Hannah. 1970. Men in Dark Times. New York: Harcourt, Brace.

Arendt, Hannah. 1972. Crises of the Republic. New York: Harcourt, Brace.

Arendt, Hannah. 1992. Hannah Arendt and Karl Jaspers: Correspondence: 1926-1969. Edited by Lotte Köhler and Hans Saner. New York: Harcourt, Brace.

Arendt, Hannah. 1994. “The Eggs Speak Up.” In Essays in Understanding, 1930-1954. New York: Harcourt, Brace.

Arendt, Hannah. 2002. "Karl Marx and the Tradition of Western Political Thought." Social Research 69 (2): 273-319.

Benhabib, Seyla. 1996. The Reluctant Modernism of Hannah Arendt. Thousand Oaks, CA: Sage.

Benjamin, Walter. 2006. "On the Concept of History." In Howard Eiland and Michael W. Jennings, eds., Walter Benjamin: Selected Writings, vol. 4. Cambridge: Belknap.

Bernasconi, Robert. 2007. "When the Real Crime Began: Hannah Arendt's The Origins of Totalitarianism and the Dignity of the Western Philosophical Tradition." In Richard King and Dan Stone, eds., Hannah Arendt and the Uses of History: Imperialism, Nation, Race, and Genocide. Oxford: Oxford University Press.

Bernstein, Richard. 1986. "Rethinking the Political and the Social." Graduate Faculty Philosophy Journal 11 (1): 111-30.

Blaut, James. 1993. The Colonizer's Model of the World: Geographical Diffusionism and Eurocentric History. New York: Guilford.

Braun, Kathrin. 2007. "Biopolitics and Temporality in Arendt and Foucault." Time and Society 16 (1): 5-23.

Canovan, Margaret. 1992. Hannah Arendt: A Reinterpretation of Her Political Thought. Cambridge: Cambridge University Press.

Chatterjee, Partha. 1993. The Nation and Its Fragments: Colonial and Postcolonial Histories. Princeton, NJ: Princeton University Press.

Chatterjee, Partha. 2011. The Lineages of Political Society: Studies in Postcolonial Democracy. New York: Columbia University Press.

Davis, Mike. 2001. Late-Victorian Holocausts: El Niño Famines and the Making of the Third World. New York: Verso.

de Angelis, Massimo. 2004. "Separating the Doing and the Deed: Capital and the Continuous Character of Enclosures." Historical Materialism 12 (2): 57-87.

Duarte, Andre de Macedo. 2007. "Hannah Arendt, Biopolitics, and the Problem of Violence: From Animal Laborans to Homo Sacer. " In Richard King and Dan Stone, eds., Hannah Arendt and the Uses of History: Imperialism, Nation, Race, and Genocide. Oxford: Oxford University Press.

Gundogdu, Ayten. 2011. "Arendt on Culture and Imperialism: Response to Klausen." Political Theory 39 (5): 661-67.

Harvey, David. 2003. The New Imperialism. Oxford: Oxford University Press. Hill, Christopher. 1972. The World Turned Upside Down: Radical Ideas During the English Revolution. New York: Viking. 
Hont, Istvan. 2005. Jealousy of Trade: International Competition and the Nation-State in Historical Perspective. Cambridge: Cambridge University Press.

Ince, Onur Ulas. 2014. "Primitive Accumulation, New Enclosures, and Global Land Grabs: A Theoretical Intervention.” Rural Sociology 79 (1): 104-31.

Jay, Martin. 1985. "The Political Existentialism of Hannah Arendt.” In Permanent Exiles: Essays on the Intellectual Migration from Germany to America. New York: Columbia University Press.

King, Richard, and Dan Stone. 2007. "Introduction.” In Richard King and Dan Stone, eds., Hannah Arendt and the Uses of History: Imperialism, Nation, Race, and Genocide. Oxford: Oxford University Press.

Klausen, Jimmy Casas. 2011. "Hannah Arendt's Antiprimitivism." Political Theory 38 (3): 394-423.

Klein, Steven. 2014. "'Fit to Enter the World': Hannah Arendt on Politics, Economics and the Welfare State." American Political Science Review 108 (4): 856-69.

Kropotkin, Peter. (1902) 2006. Mutual Aid: A Factor of Evolution. New York: Dover.

Leonard, Stephen T. 1997. "Evil, Violence, Thinking, Judgment: Working in the Breach of Politics." In Craig Calhoun and John McGowan, eds., Hannah Arendt and the Meaning of Politics. Minneapolis: University of Minnesota Press.

Linebaugh, Peter, and Marcus Rediker. 2000. The Many Headed Hydra: Sailors, Slaves, Commoners, and the Hidden History of the Revolutionary Atlantic. Boston: Beacon.

Luxemburg, Rosa. (1913) 2003. The Accumulation of Capital. London: Routledge.

Mantena, Karuna. 2002. "Arendt on the Logic and Legacy of Imperialism.” In Richard King and Dan Stone, eds., Hannah Arendt and the Uses of History: Imperialism, Nation, Race, and Genocide. Oxford: Oxford University Press.

Marx, Karl. (1867) 1976. Capital: A Critique of Political Economy, vol. 1. London: Penguin.

Markell, Patchen. 2008. “The Insufficiency of Non-Domination.” Political Theory 36 (1): 9-36.

Markell, Patchen. 2011. "Arendt's Work: On the Architecture of the Human Condition." College Literature 38 (1): 15-44.

McClure, Kirstie. 2007. "The Social Question, Again.” Graduate Faculty Philosophy Journal 28 (1): 85-113.

McGowan, John. 1997a. Hannah Arendt: An Introduction. Minneapolis: University of Minnesota Press.

McGowan, John. 1997b. "Must Politics Be Violent? Arendt's Utopian Vision." In Craig Calhoun and John McGowan, eds., Hannah Arendt and the Meaning of Politics. Minneapolis: University of Minnesota Press.

Owens, Patricia. 2011. "The Supreme Social Concept: The Un-Worldliness of Modern Security." New Formations 71 (1): 14-29.

Owens, Patricia. 2012a. "Human Security and the Rise of the Social." Review of International Studies 38 (3): 547-67.

Owens, Patricia. 2012b. "Not Life but the World Is at Stake: Hannah Arendt on Citizenship in the Age of the Social." Citizenship Studies 16 (2): 297-307.
Pahuja, Sundhya. 2011. Decolonising International Law: Development, Economic Growth, and the Politics of Universality. Cambridge: Cambridge University Press.

Pateman, Carole. 2007. "The Settler Contract.” In Carol Pateman and Charles W. Mills, eds., The Contract and Domination. Malden: Polity.

Peet, Robert, and Elaine Hartwick. 2009. Theories of Development: Contentions, Arguments, Alternatives. 2nd ed. London: Guilford.

Pincus, Steve. 1998. "Neither Machiavellian Moment nor Possessive Individualism: Commercial Society and the Defenders of the English Commonwealth." American Historical Review 103 (3): 705-26.

Pincus, Steve. 2009. 1688: The First Modern Revolution. New Haven, CT: Yale University Press.

Pitkin, Hanna Fenichel. 1981. "Justice: On Relating Private and Public." Political Theory 9 (3): 327-52.

Pitkin, Hanna Fenichel. 1998. The Attack of the Blob: Hannah Arendt's Conception of the Social. Chicago: University of Chicago Press.

Polanyi, Karl. (1944) 2001. The Great Transformation: The Political and Economic Origins of Our Time. Boston: Beacon.

Rana, Aziz. 2010. The Two Faces of American Freedom. Cambridge, MA: Harvard University Press.

Ring, Jennifer. 1989. "On Needing Both Marx and Arendt: Alienation and the Flight from the Inwardness." Political Theory 17 (3): 432-48.

Rist, Gilbert. 2009. The History of Development: From Western Origins to Global Faith. 3rd ed. London: Zed.

Rostow, Walt W. 1960. Stages of Economic Growth: A Non-Communist Manifesto. Cambridge: Cambridge University Press.

Sanyal, Kalyan. 2007. Rethinking Capitalist Development: Primitive Accumulation, Governmentality and Post-Colonial Capitalism. New Delhi: Routledge.

Schmitt, Carl. (1950) 2003. The Nomos of the Earth in the International Law of the Jus Publicum Europaeum. New York: Telos.

Shanin, Teodor. 1983. Late Marx and the Russian Road: Marx and the Peripheries of Capitalism. New York: Monthly Review Press.

Terada, Rei. 2011. "The Life Process and Forgettable Living: Arendt and Agamben." New Formations 71 (1): 95-109.

Tsao, Roy. 2002. "Arendt against Athens: Rereading the Human Condition." Political Theory 30 (1): 97-123.

Tully, James. 2009. “Lineages of Contemporary Imperialism.” In Duncan Kelly, ed., Lineages of Empire: The Historical Roots of British Imperial Thought. Oxford: Oxford University Press.

Villa, Dana. 2000. "Introduction: The Development of Arendt's Political Thought.” In Dana Villa, ed., Cambridge Companion to Hannah Arendt. Cambridge: Cambridge University Press.

Yaqoob, Waseem. 2014. "Reconciliation and Violence: Hannah Arendt on Historical Understanding.” Modern Intellectual History 11 (2): 385-416.

Young-Bruehl, Elisabeth. 1982. Hannah Arendt: For Love of the World. New Haven, CT: Yale University Press.

Zaretsky, Eli. 1997. "Hannah Arendt and the Meaning of the Public/Private Distinction." In Craig Calhoun and John McGowan, eds., Hannah Arendt and the Meaning of Politics. Minneapolis: University of Minnesota Press. 
Copyright of Journal of Politics is the property of University of Chicago Press and its content may not be copied or emailed to multiple sites or posted to a listserv without the copyright

holder's express written permission. However, users may print, download, or email articles for individual use. 